Journal homepage:http://www.journalijar.com

INTERNATIONAL JOURNAL

Journal DOI:10.21474/IJAR01

OF ADVANCED RESEARCH

RESEARCH ARTICLE

ISSN NO. 2320-5407

\title{
RESPIRATION RATE OF OYSTER MUSHROOMS - EFFECT OF TIME, TEMPERATURE AND GAS CONCENTRATION AND ITS KINETIC MODELLING.
}

"Sudhanshu Billoria and Hari Niwas Mishra.

Agricultural \& Food Engineering Department, Indian Institute of Technology Kharagpur, Kharagpur, West Bengal 721302, India.

\section{Manuscript Info Abstract}

\section{Manuscript History:}

Received: 15 April 2016

Final Accepted: 29 May 2016

Published Online: June 2016

Key words:

Oyster mushroom, respiration rate, enzyme kinetics, Peleg model, modeling

*Corresponding Author

Cortesponding Author

Sudhanshu Billoria.
Experiments were conducted for the measurement of respiration rate of oyster mushrooms at seven different storage temperatures $(0,5,10,15,20$, 25 ad $30^{\circ} \mathrm{C}$ ) using the closed system respirometer method. The effect of time, temperature and gas concentration on the respiration rate of oyster mushroom was studied and the models involving these parameters were developed. The experimental data were fitted to two different mathematical models; Peleg model, and an uncompetitive inhibition based enzyme kinetics model, for the prediction of respiration rate within the given experimental range. The suitability of models to predict the respiration rate was examined with the help of relative deviation modulus by calculating the difference between the actual and the predicted respiration rates at $3{ }^{\circ} \mathrm{C}$. The mean relative deviation moduli of predicted versus experimental respiration rates were found to be $10.3 \%$ and $11.2 \%$ for $\mathrm{O}_{2}$ and $\mathrm{CO}_{2}$ respiration expressions of Peleg model and $9.3 \%$ and $8.5 \%$ for $\mathrm{O}_{2}$ and $\mathrm{CO}_{2}$ for uncompetitive inhibition based enzyme kinetics model, respectively. The uncompetitive inhibition based enzyme kinetics model showed better agreement with the actual respiration rate than the Peleg model.

Copy Right, IJAR, 2016... All rights reserved

\section{NOMENCLATURE}

\begin{tabular}{|l|l|}
\hline$a$ & Peleg rate constant, $\mathrm{h}^{-1}$ \\
\hline$b$ & Peleg capacity constant, $\%^{-1}$ \\
\hline$E$ & mean relative deviation modulus, $\%$ \\
\hline$E_{\mathrm{a}}$ & activation energy, $\mathrm{kJ} \mathrm{g}^{-1} \mathrm{~mol}^{-1}$ \\
\hline$G_{\mathrm{CO} 2}$ & carbon dioxide concentration, $\%$ \\
\hline$G_{\mathrm{O} 2}$ & oxygen concentration, $\%$ \\
\hline$K_{\mathrm{i}(\mathrm{CO} 2)}$ & inhibition constant for $\mathrm{CO}_{2}$ evolution, $\% \mathrm{CO}_{2}$ \\
\hline$K_{\mathrm{i}(\mathrm{O} 2)}$ & inhibition constant for $\mathrm{O}_{2}$ consumption, $\% \mathrm{CO}_{2}$ \\
\hline$K_{m(\mathrm{O} 2) \mathrm{f}}$ & inhibition constant of $\mathrm{O}_{2}$ on fermentative $\mathrm{CO}_{2}$ production rate, $\% \mathrm{CO}_{2}$ \\
\hline$K_{\mathrm{m}(\mathrm{CO} 2)}$ & Michaelis-Menten constant for $\mathrm{CO}_{2}$ evolution, $\% \mathrm{O}_{2}$ \\
\hline$K_{\mathrm{m}(\mathrm{O} 2)}$ & Michaelis-Menten constant for $\mathrm{O}_{2}$ consumption, $\% \mathrm{O}_{2}$ \\
\hline$N$ & number of respiration data points \\
\hline$R$ & universal gas constant, $8.314, \mathrm{~kJ} \mathrm{~g}^{-1}$ mol ${ }^{-1} \mathrm{~K}$ \\
\hline$R_{\mathrm{CO} 2}$ & respiration rate, mL $\left[\mathrm{CO}_{2}\right] \mathrm{kg}^{-1} \mathrm{~h}^{-1}$ \\
\hline$R_{\mathrm{m}}$ & model parameter for Michaelis-Menten equation \\
\hline$R_{\mathrm{O} 2}$ & respiration rate, $\mathrm{mL}\left[\mathrm{O}_{2}\right] \mathrm{kg}^{-1} \mathrm{~h}^{-1}$ \\
\hline$R_{\mathrm{p}}$ & respiration pre-exponential constant factor \\
\hline$T$ & storage temperature, ${ }^{\circ} \mathrm{C}$ \\
\hline$t$ & storage time, $\mathrm{h}$ \\
\hline
\end{tabular}




\begin{tabular}{|l|l|}
\hline$T_{\text {abs }}$ & absolute temperature, $\mathrm{K}$ \\
\hline$T_{\text {ref }}$ & reference temperature, $\mathrm{K}$ \\
\hline$\Delta t$ & time difference between two gas measurements, $\mathrm{h}$ \\
\hline$V_{\mathrm{fr}}$ & free volume of the respiration chamber, $\mathrm{mL}$ \\
\hline$V_{\mathrm{m}(\mathrm{CO} 2)}$ & maximum oxidative respiration rate for $\mathrm{CO}_{2}$ evolution, $\mathrm{mL} \mathrm{kg}^{-1} \mathrm{~h}^{-1}$ \\
\hline$V_{\mathrm{m}(\mathrm{O} 2)}$ & maximum fermentation rate for $\mathrm{O}_{2}$ consumption, $\mathrm{mL} \mathrm{kg} \mathrm{h}^{-1}$ \\
\hline$V_{m(\mathrm{CO} 2) f}$ & maximum respiration rate for $\mathrm{CO}_{2}$ evolution, $\mathrm{mL} \mathrm{kg} \mathrm{h}^{-1}$ \\
\hline$W$ & mass of fruit, $\mathrm{kg}$ \\
\hline
\end{tabular}

\section{Introduction:-}

There are considerable postharvest losses in the horticultural commodities and mushroom is one of those highly perishable commodities(Bano et. al., 1988; Villaescusa and Gill, 2003). The major factor that leads to shorter shelf life of mushrooms is its high respiration rate, which is 28.2-43.6 $\mathrm{mg} \mathrm{CO}_{2}$ per $\mathrm{kg}$ fresh weight per hour at $0{ }^{\circ} \mathrm{C}$ for button mushrooms(Hammond and Nichols, 1975; USDA, 1977).

Mushrooms undergo various other physiological processes also after harvesting, which include growth, maturation, senescence, weight loss, veil-opening, browning and wilting(Rai and Arumuganathan, 2008). These processes are also responsible for the short shelf life of the mushrooms. There are various types of mushrooms among which Agaricus bisporus (button mushroom), Lentinus edodes (shiitake mushroom), Pleurotus spp (oyster mushrooms), Auricula spp (wood ear), Flamulina velutipes (enokitake) and Volvariella volvacea (straw mushroom) are the commonly cultivated mushrooms (Aida et al., 2009). Nearly all the mushrooms have poor shelf-life, whereas the oyster mushroom has even poorer (few hours at the ambient conditions).

The number of recognized mushroom species has been reported to be 14,000 , which is just $10 \%$ of the total estimated mushroom species on the earth (Cheung, 2008; Koushki et al., 2011). Total commercial mushroom production worldwide has increased from about 350,000 tons in 1965 to about 3.4 million metric tons (Koopman and Laney, 2010). However, references regarding the respiration rate of these varieties are scarce in the literature. Measurement of respiration rate of produce at a particular storage temperature and gas composition is time consuming and requires special equipment for gas analysis (Cameron et al., 1989; Bhande and Goswami, 2008).

In order to prolong the availability in the market throughout the year, the perishable commodities need to be handled and stored with due care. Certain postharvest constraints, including short shelf life, moisture loss, ripening and susceptibility to diseases limit their long duration storage and transportation (Mangaraj and Goswami, 2011).Researchers have extended the shelf life by studying the influence of altered atmospheres such as modified atmosphere and controlled atmosphere (MA and CA) of the commodity in storage. These methods provide control of moisture loss, retardation of senescence and browning in cut produce, reduction in respiration rate and ultimately prolong the shelf life. Depending on the specific requirements, MA and CA can extend market availability of the produce up to the next harvest (Mangaraj and Goswami, 2011).

As respiration rate is an important factor (Hammond and Nichols, 1975), its decrease or careful alteration and manipulation can help in achieving the extended shelf life of the commodity. Product type and variety, production conditions, maturity stage at harvest, ageing (time), temperature, gas composition, and cutting (mechanical damage) are important internal and external factors influencing the respiration rate of the fresh produce (Menon and Goswami, 2008; Iqbal et al., 2009; Li et al., 2009). In addition to this, manipulation of storage conditions also results in the lowered enzymatic activities leading to extended storage life and reduction in the utilization of the respiratory substrates.

Peleg model and uncompetitive inhibition based enzyme kinetics model were the commonly used models (Hagger $e t$ al., 1992; Mahajan and Goswami, 2001; Bhande and Goswami, 2008; Menon and Goswami, 2008; Mangaraj and Goswami, 2011). Although a number of other models were also proposed by the researchers for the prediction of respiration rate of various fruits and vegetables, the majority of the models

has been developed by either considering the respiration rate as a function of the gas concentration or the time elapsed (Yang \& Chinnan, 1988; Cameron et al., 1989; Talasila et al., 1992; Lee et al., 1991; Hagger et al., 1992; Makino et al., 1996). Among the models, the most theoretically based model is the Michaelis-Menten equation 
which is based on the principle of enzyme kinetics but simplifies the complex pathway of respiration assuming it to be based on one limiting enzymatic reaction where the substrate is $\mathrm{O}_{2}$ (Mangaraj and Goswami, 2011).

Nevertheless, studies regarding respiration modeling and postharvest preservation techniques for Agaricus bisporus (Byrnes and O'Beirne, 2007; Iqbal et al., 2009; Li et al., 2009; Oliveira et al., 2012) were abundantly found in the literature, information on the respiration rate of other species like oyster mushrooms (Pleurotus ostreatus) is scarce. Few studies on MAP of some of Pleurotus sps. such as P. ostreatus, P. sajor-caju and P. eryngii(Sapata et al., 2009; Villaescusa and Gill, 2009) were found, but sufficient amount of respiration rate modelling of oyster mushrooms is still lacking. Azevedo et al.(2014) studied and modelled the effect of temperature and time on respiration rate of fresh oyster mushroom. However, the gas concentration along with the storage time and the temperature is an important factor that influences the respiration rate of a commodity (Menon and Goswami, 2008; Peppelenbos, 1996). Therefore, the need was realized to develop models that include the effect of gas concentration, storage time and temperature on the respiration rate of oyster mushrooms. The models were suitably modified for temperature dependence based on the linear model fitting and using an Arrhenius type of relationship (incorporating reference temperature) in Arrhenius equation (Lakakul et al., 1999; Hertog et al., 1998).

For the sake of simplicity and to prevent confusion, the model parameters for the enzyme kinetics model may be mentioned as $V_{m}, K_{m}$ and $K_{i}$ when mentioned in their generalized forms instead of writing all their forms separately, such as $V_{m O 2}, V_{m C O 2 o x}$ and $V_{m(\mathrm{CO}) f}$ or $V_{m}$ and $K_{m O 2}$ and $K_{m \mathrm{CO} 2}$ for $K_{m}$ and $K_{i \mathrm{O} 2}, K_{i \mathrm{CO} 2 \mathrm{ox}}$ and $K_{m(\mathrm{O} 2) \mathrm{f}}$ until mentioned otherwise.

\section{Materials and methods:-}

\section{Measurement of Respiration Rate:-}

Fresh mushrooms (Pleurotus ostreatus) were obtained from the experimental farm of Agricultural \& Food Engineering Department, Indian Institute of Technology Kharagpur, West Bengal, India. These were washed to remove adhering dirt before using for the experiments. It was ensured that the mushrooms were of uniform size, mass and maturity (depending on color and size of the mushrooms). The sample used for study varied from $0.044 \mathrm{~m}$ to $0.060 \mathrm{~m}$ in circumference of the veil.

The respiration rate was measured using closed system respirometer (Cameron et al., 1989; Hagger et al., 1992; Morales-Castro et al., 1994; Lee and Lee, 1996; Hong and Kim, 2011; Mahajan and Goswami, 2001; Fonseca et al., 2002; Song et al., 2002; Menon and Goswami, 2008; Bhande et al.,2008; Iqbal et al., 2009; Mangaraj and Goswami, 2011), as this method is more convenient and simpler than continuous flow method which is technically difficult because of the need of highly accurate analytical equipment (Cameron et al., 1989). The sample was kept in airtight respirometer chambers made up of acrylic sheets having dimensions $0.2 \times 0.2 \times 0.18 \mathrm{~m}$ and volume $7200 \mathrm{mLthat}$ were previously equilibrated with the experimental temperature.

Alternatively, another set of experiments was conducted at the same conditions except that after the measurement of gas concentration, the respirometer container was kept open for $10 \mathrm{~min}$ so that it gets replenished with new air. This was done in order to study the effect of time on the respiration rate of mushrooms as the time progressed without changing the gas concentration.

The respirometer containers were kept in thermostatically controlled test chambers which were maintained at the desired temperatures with a tolerance limit of $\pm 0.5^{\circ} \mathrm{C}$. Gas composition of respirometer was analyzed at regular intervals depending on the storage temperature of mushrooms. The sampling interval was varied depending on the rate of respiration at different temperatures, as at higher temperature the rate of evolution of $\mathrm{CO}_{2}$ and consumption of $\mathrm{O}_{2}$ was faster, therefore, the sampling was done at shorter intervals and for lower temperatures long sampling interval was chosen because of the lowered respiration rates. In the headspace analyzer, a zirconium sensor is used for $\mathrm{O}_{2}$ determination and an infrared detector is used to detect $\mathrm{CO}_{2}$. The change in gas concentration was measured till the aerobic respiration persisted(i.e. $\mathrm{O}_{2}$ concentrations reached $0 \%$ ). The responses studied were $R_{\mathrm{CO} 2}, R_{\mathrm{O} 2}$ and $R Q$ with respect to changes in temperature and time. All measurements were taken in triplicate.

\section{Data Analysis:-}

The respiration rates in terms of $\mathrm{CO}_{2}$ and $\mathrm{O}_{2}$ at a given temperature were calculated using the following Eqs. (1-3) as given by Kays (1991):

$R_{\mathrm{CO}_{2}}=\left[\frac{\left(G_{\mathrm{CO}_{2}}\right)_{t+1}-\left(G_{\mathrm{CO}_{2}}\right)_{t}}{\Delta t}\right] \frac{V_{f r}}{W}$ 
(2) $R_{O_{2}}=\left[\frac{\left(G_{O_{2}}\right)_{t}-\left(G_{O_{2}}\right)_{t+1}}{\Delta t}\right] \frac{V_{f r}}{W}$

$$
R Q=\frac{R_{C O 2}}{R_{O 2}}
$$

Where, $R_{\mathrm{O} 2}$ is the respiration rate, $\mathrm{mL} \mathrm{O}_{2} \mathrm{~kg}^{-1} \mathrm{~h}^{-1} ; R_{\mathrm{CO} 2}$ is the respiration rate, $\mathrm{mL} \mathrm{CO}_{2} \mathrm{~kg}^{-1} \mathrm{~h}^{-1} ; G_{\mathrm{O} 2}$ and $G_{\mathrm{CO} 2}$ are the gas concentrations (\%) of $\mathrm{O}_{2}$ and $\mathrm{CO}_{2}$, respectively (Bhande and Goswami, 2008; Menon and Goswami. 2008; Iqbal et al., 2009; Mangaraj and Goswami, 2011); $t$ is the storage time in hours; $\Delta t$ is the time difference between two gas measurements; $V_{\mathrm{fr}}$ is the free volume of the respiration chamber in $\mathrm{mL}$ and $W$ is the mass of the fruit in $\mathrm{kg}$. Mass of mushrooms and free volume of respirometer taken during the experiment is presented in Table 1 . The volume of mushrooms was measured by water displacement method and free volume was calculated by subtracting the volume of mushrooms from the total volume of respirometer.

Table 1:- Free volume of respirometer and weight of mushrooms taken for generating the respiration data ${ }^{\mathrm{a}}$

\begin{tabular}{|l|l|l|}
\hline Storage temperature $\left({ }^{\circ} \mathrm{C}\right)$ & Weight of mushrooms, $W(\mathrm{~kg})$ & Free volume of respirometer, $V_{\text {fr }}(\mathrm{mL})$ \\
\hline 0 & $0.579 \pm 0.03$ & $6410 \pm 84.81$ \\
\hline 5 & $0.498 \pm 0.08$ & $6508 \pm 111.87$ \\
\hline 10 & $0.510 \pm 0.11$ & $6523 \pm 95.27$ \\
\hline 15 & $0.500 \pm 0.09$ & $6536 \pm 126.65$ \\
\hline 20 & $0.532 \pm 0.12$ & $6493 \pm 94.83$ \\
\hline 25 & $0.515 \pm 0.07$ & $6516 \pm 88.12$ \\
\hline 30 & $0.556 \pm 0.12$ & $6460 \pm 103.9$ \\
\hline
\end{tabular}

${ }^{a}$ Values are average of three replications and values after \pm are standard deviation.

\section{Respiration Rate Modeling:- \\ Model 1 (Peleg Model)}

Experimental respiration data in which the container was kept open for $10 \mathrm{~min}$ to replenish the air was used to perform nonlinear regression analysis (OriginPro 8.5) to fit $\mathrm{O}_{2}$ and $\mathrm{CO}_{2}$ concentration at different storage time periods. The respiration rate at a given time is determined from the first derivative of the regression function (Cameron et al., 1989; Hagger et al., 1992; Mahajan and Goswami, 2001; Bhande and Goswami, 2008; Menon and Goswami, 2008; Mangaraj and Goswami, 2011).Respiration rates can be theoretically obtained by measuring the slope of the graph of gas concentration versus time. However, this method is not recommended since data sets have large experimental variations (Mangaraj and Goswami, 2011). Instead, a regression function (Eqs. 4 and 5) is often used to fit the gas concentration data versus time and the rate of change of gas concentration was determined from the first derivative of the regression functions as outlined in Eqs. 6 and 7.

$$
\begin{aligned}
& G_{C_{2}}=\frac{t}{(a t+b)} \\
& G_{O_{2}}=0.21-\left[\frac{t}{a t+b}\right]
\end{aligned}
$$

Where, $\mathrm{GCO}_{2}$ and $\mathrm{GO}_{2}$ are the gas concentrations of $\mathrm{CO}_{2}(\%)$ and $\mathrm{O}_{2}(\%)$, respectively, $t$ is the time in hour, $a\left(\mathrm{~h} \%^{-1}\right.$ ) is a Peleg rate constant and $b\left(\%^{-1}\right)$ is a Peleg capacity constant. The rate of change of gas concentration was determined from the first derivative of the regression functions as outlined in Eqs. (6) and (7) and then substituted in Eqs. (8) and (9) to calculate the respiration rate of mushrooms at any given conditions within the experimental range.

$$
\frac{d G_{C O_{2}}}{d t}=-a t(a t+b)^{-2}+(a t+b)^{-1}
$$




$$
\begin{aligned}
& \frac{d G_{\mathrm{O}_{2}}}{d t}=a t(a t+b)^{-2}-(a t+b)^{-1} \\
& R_{\mathrm{CO}_{2}}=\frac{d\left[G_{\mathrm{CO}_{2}}\right]}{d t} \frac{V_{f r}}{W} \\
& R_{\mathrm{O}_{2}}=-\frac{d\left[G_{O_{2}}\right]}{d t} \frac{V_{f r}}{W}
\end{aligned}
$$

A similar model was applied to the respiration data of apples by Mahajan and Goswami (2001), for banana by Bhande and Goswami (2008) and other researchers (Cameron et al., 1989; Hagger et al., 1992; Menon and Goswami, 2008; Mangaraj and Goswami, 2011). According to the previous studies, the values of model parameters at given temperature could hitherto be predicted by linear interpolation of the values. Therefore, the linear regression analysis was performed on the values of model parameters at different temperatures. The equations found can be used to calculate the value of model parameters ( $a$ and $b$ for both $\mathrm{CO}_{2}$ evolution and $\mathrm{O}_{2}$ consumption) at given temperatures.

\section{Model 2 (Uncompetitive Inhibition based Enzyme Kinetics Model)}

Uncompetitive inhibition based enzyme kinetics model was developed to predict the respiration rate on the basis of consideration that $\mathrm{CO}_{2}$ acts as a respiratory inhibitor (McLaughlin and O'Beirne, 1999). But the production of $\mathrm{CO}_{2}$ is attributed to two processes - a fermentative part, which is inhibited at high $\mathrm{O}_{2}$ concentrations, and an oxidative part, almost negligible at very low $\mathrm{O}_{2}$ concentrations (Peppelenboset al., 1996; Hertoget al., 1998; Lammertynet al., 2003; Ho et al., 2008; Ho et al., 2010). The first part in equations 11 and 13 is $\mathrm{CO}_{2}$ production by oxidative respiration and the second part is by the fermentation. The linearized forms (Eqs. 12 and 13) of the equations (10 and 11) were fitted to the gas concentrations at different storage time using multiple linear regression analysis (OriginPro 8.5).

However, at high levels of $\mathrm{CO}_{2}$ concentration (18\%)and reduced levels of $\mathrm{O}_{2}$ concentration $(0 \%)$ the respiration mechanism changes from aerobic to anaerobic pathway (Mahajan and Goswami,2001; Bhande and Goswami, 2008).The model parameters (Eqs. 10 and 11), $V_{\mathrm{m}}, K_{\mathrm{m}}$, and $K_{\mathrm{i}}$ for $\mathrm{O}_{2}$ consumption and $\mathrm{CO}_{2}$ evolution were determined using the experimental respiration data. The Eqs. 10 and 11 were converted to their linearized forms (Eqs. 12 and 13) to estimate the model parameters by multiple linear regression analysis using OriginPro 8.5.

$$
\begin{aligned}
& R_{\mathrm{CO}_{2}}=\left[\frac{V_{m\left(\mathrm{CO}_{2}\right)} G_{\mathrm{O}_{2}}}{K_{m\left(\mathrm{CO}_{2}\right)}+\left(1+\frac{G_{\mathrm{CO}_{2}}}{K_{i\left(\mathrm{CO}_{2}\right)}}\right) G_{\mathrm{O}_{2}}}\right]+\left[\frac{V_{m\left(\mathrm{CO}_{2}\right) f}}{\left(1+\frac{G_{\mathrm{CO}_{2}}}{K_{m\left(\mathrm{O}_{2}\right) f}}\right)}\right] \\
& R_{\mathrm{CO}_{2}}=R Q \times R O_{2}+\frac{V_{m\left(\mathrm{CO}_{2}\right) f}}{\left(1+\frac{G_{\mathrm{CO}_{2}}}{K_{m\left(\mathrm{O}_{2}\right) f}}\right)} \\
& R_{O_{2}}=\frac{V_{m\left(O_{2}\right)} G_{O_{2}}}{K_{m\left(O_{2}\right)}+\left[1+\frac{G_{C_{2}}}{K_{i\left(O_{2}\right)}}\right] G_{O_{2}}} \\
& \frac{1}{R_{\mathrm{CO}_{2}}}=\left[\frac{1}{V_{m(\mathrm{CO})}}+\left(\frac{K_{m\left(\mathrm{CO}_{2}\right)}}{V_{m\left(\mathrm{CO} O_{2}\right)}} \times \frac{1}{G_{O_{2}}}\right)+\left(\frac{1}{K_{i\left(\mathrm{CO}_{2}\right)} \times V_{m\left(\mathrm{CO}_{2}\right)}} \times G_{\mathrm{CO}_{2}}\right)\right]+\left[\frac{1}{V_{m\left(\mathrm{CO}_{2}\right) f}}+\left(\frac{1}{V_{m\left(\mathrm{CO}_{2}\right) f} \times K_{m\left(O_{2}\right) f}} \times G_{\mathrm{CO}_{2}}\right)\right]
\end{aligned}
$$

Or 


$$
\frac{1}{R_{O_{2}}}=\frac{1}{V_{m\left(O_{2}\right)}}+\left(\frac{K_{m\left(O_{2}\right)}}{V_{m\left(O_{2}\right)}} \times \frac{1}{G_{O_{2}}}\right)+\left(\frac{1}{K_{i\left(O_{2}\right)} \times V_{m\left(O_{2}\right)}} \times G_{C O_{2}}\right)
$$

Where, $V_{m(O 2)}$ is the maximum $\mathrm{O}_{2}$ consumption rate; $V_{m(\mathrm{CO})}$ and $V_{m(\mathrm{CO}) \text { fare }}$ the maximum $\mathrm{CO}_{2}$ production rates by oxidative respiration and fermentation $\left(\mathrm{mL}^{\mathrm{kg}} \mathrm{kg}^{-1} \cdot \mathrm{h}^{-1}\right)$ respectively; $K_{\mathrm{mO} 2}$ and $K_{\mathrm{mCO} 2}$ are the Michaelis-Menten constants for $\mathrm{O}_{2}$ consumption and $\mathrm{CO}_{2}$ evolution $\left(\% \mathrm{O}_{2}\right)$, respectively; and $K_{\mathrm{iO} 2}$ and $K_{\mathrm{iCO} 2}$ are the inhibition constants for $\mathrm{O}_{2}$ consumption and $\mathrm{CO}_{2}$ evolution $\left(\% \mathrm{CO}_{2}\right)$, respectively, $K_{m(O 2) f}$ is the inhibition constant of $\mathrm{O}_{2}$ on fermentative $\mathrm{CO}_{2}$ production rate $\left(\% \mathrm{O}_{2}\right) ; G_{\mathrm{CO} 2}$ and $G_{\mathrm{O} 2}$ are gaseous concentrations of $\mathrm{CO}_{2}$ and $\mathrm{O}_{2}(\%)$.

The model parameters obtained were correlated at different temperatures using Arrhenius equation (Bhande and Goswami, 2008; Mangaraj and Goswami, 2011). However, the mathematical structure of the Arrhenius equation as proposed by Bhande and Goswami (2008); Menon and Goswami (2008) involving the exponentiation of the reciprocal of the absolute temperature, introduces a high correlation between two parameter estimates making parameter estimation difficult. To overcome this complication, the Arrhenius equation was represented in its linear form by Mangaraj and Goswami (2011). In order to further minimize the high correlation among the parameters of the Arrhenius equation, reparameterization was suggested by Schwaab and Pinto (2007). The reparameterization can be attained by involving a new temperature term $T_{\text {ref }}$ into the Arrhenius equation which is the reference temperature and is the average temperature of analyzed experimental range. The proper selection of the reference temperature (Eq. 14) allows the estimation of uncorrelated parameters and simultaneous improvement of the precision of the parameter estimates in problems involving a single kinetic constant (Schwaab and Pinto, 2007).

$$
\begin{aligned}
& R_{m}=R_{p} \exp \left[\frac{-E_{a}}{R} \times\left(\frac{1}{T_{a b s}}-\frac{1}{T_{r e f}}\right)\right] \\
& \ln R_{m}=\left[\frac{-E_{a}}{R} \times\left(\frac{1}{T_{a b s}}-\frac{1}{T_{r e f}}\right)\right]+\ln R_{p}
\end{aligned}
$$

$R_{\mathrm{m}}$ is the generalized form of model parameters (i.e. $V_{\mathrm{m}}, K_{\mathrm{m}}$, and $K_{\mathrm{i}}$ ), $R_{\mathrm{p}}$ is respiration pre-exponential factor, $E_{\mathrm{a}}$ is the activation energy $\left(\mathrm{kJ} \mathrm{g}^{-1} \mathrm{~mol}^{-1}\right), R$ is the universal gas constant $\left(\mathrm{kJ} \mathrm{g}^{-1} \mathrm{~mol}^{-1} \mathrm{~K}\right)$ and $T_{\text {abs }}$ is the absolute temperature (K) and $T_{\text {ref }}$ is the reference temperature (K).

\section{Validation of the models:-}

The suitability of models to predict the respiration rate was examined by using the relative deviation modulus (Eq. 16) by calculating the difference between the actual and the predicted respiration rates at $3{ }^{\circ} \mathrm{C}$. The experimental respiration rate of the mushrooms in terms of $\mathrm{CO}_{2}$ evolution and $\mathrm{O}_{2}$ consumption was calculated using Eqs. 1 and 2 respectively. Moduli below 10\% are indicative of reasonably close fit, $10-20 \%$ fairly close fit and 20-30\% not satisfactory fit for all practical purposes.

$$
E=\frac{100}{N} \sum_{1}^{N} \frac{\left|\left(R_{\text {exp }}-R_{\text {pre }}\right)\right|}{R_{\text {exp }}}
$$

Where, $E$ is the average relative deviation modulus, $\% ; N$ is the number of respiration data points; $R_{\exp }$ is the experimental respiration rate, $\mathrm{mL} \mathrm{kg}^{-1} \mathrm{~h}^{-1}$ and $R_{\text {pre }}$ is the predicted respiration rate $\mathrm{mL} \mathrm{kg}^{-1} \mathrm{~h}^{-1}$. In general, lower modulus shows the close agreement between the predicted and the experimental values. The free volume and weight of the mushrooms taken for the validation were $6518 \mathrm{~mL}$ and $0.511 \mathrm{~kg}$, respectively. The initial gas concentration of the respirometer was kept $18 \% \mathrm{O}_{2}$ and $3 \% \mathrm{CO}_{2}$ to see the influence of gas concentration on the suitability of prediction models.

\section{Results and discussion:-}

Effect of temperature and gas concentration on the respiration rate:-

Expectedly, the respiration rate increased significantly $(\mathrm{P}<0.05)$ with the rise in temperature and it was recorded as $29.52 \pm 0.33$ and $40.59 \pm 0.45$ at $0{ }^{\circ} \mathrm{C}$ and $360.18 \pm 0.43$ and $395.06 \pm 0.38$ at $30^{\circ} \mathrm{C}$ in terms of $\mathrm{CO}_{2}$ evolution $(\mathrm{mL}$ of $\mathrm{CO}_{2} \mathrm{~kg}^{-1} \mathrm{~h}^{-1}$ ) and $\mathrm{O}_{2}$ consumption $\left(\mathrm{mL}\right.$ of $\mathrm{O}_{2} \mathrm{~kg}^{-1} \mathrm{~h}^{-1}$ ),respectively. Moreover, the gas concentrations reached their upper limits $\left(\mathrm{CO}_{2}>18 \%\right.$ and $\left.0 \% \mathrm{O}_{2}\right)$ in $80 \mathrm{~h}$ at $5^{\circ} \mathrm{C}$ and in $28 \mathrm{~h}$ at $15^{\circ} \mathrm{C}$ as can be seen from Figure 1 (Salveit, 2004). 

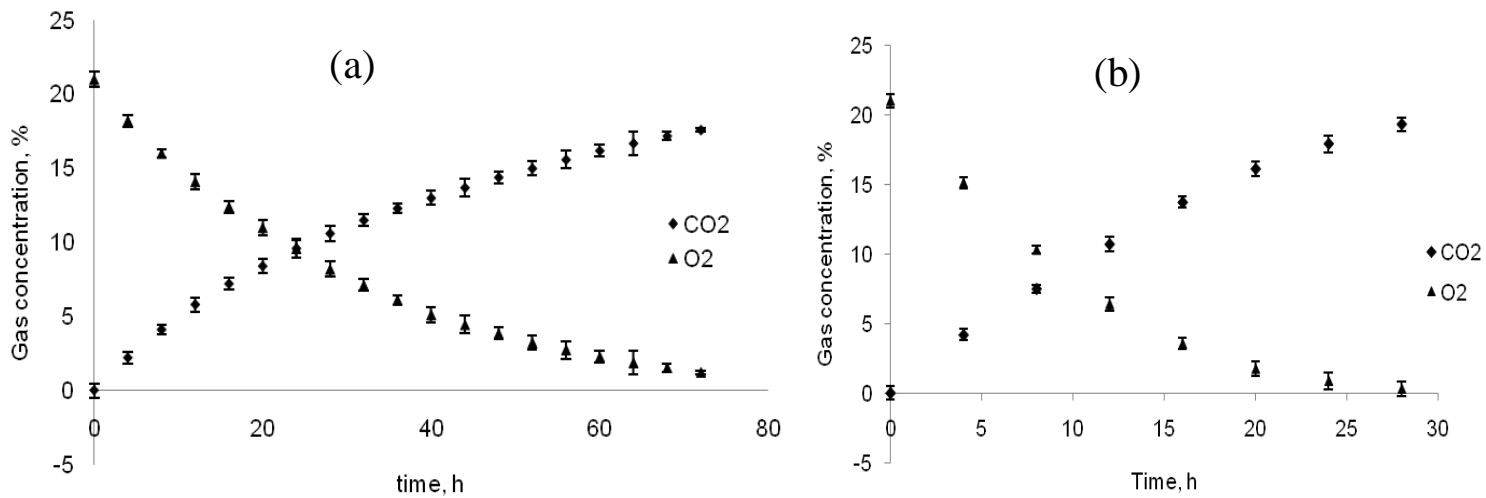

Figure 1:- Gas concentrations of $\mathrm{CO}_{2}$ and $\mathrm{O}_{2}$ at (a) $5{ }^{\circ} \mathrm{C}$ and (b) $15^{\circ} \mathrm{C}$. Data correspond to the mean $\pm \mathrm{SE}$ of the independent triplicates.

Though the respiration rate increased with the increase in temperature, it followed a decreasing trend with the progress in time due to the increase in $\mathrm{CO}_{2}$ concentration and the decrease in $\mathrm{O}_{2}$ concentration (Bhande and Goswami, 2008; Menon and Goswami, 2008). At the outset of the experiment, the initial respiration rate was higher, i.e. 29.52 and $40.59\left(\mathrm{~mL} \mathrm{~kg}^{-1} \mathrm{~h}^{-1}\right)$ but it reduced to 6.80 and 6.29 in terms of $\mathrm{CO}_{2}$ evolution and $\mathrm{O}_{2}$ consumption, respectively, after the accumulation of $18.3 \%$ of $\mathrm{CO}_{2}$ and reduction of $\mathrm{O}_{2}$ to $0.75 \%$ at $0{ }^{\circ} \mathrm{C}$. This can be attributed to the inhibitory effect of $\mathrm{CO}_{2}$ on the rate of respiration. A similar trend is clearly reflected in Figure 2 by the gradual reduction in the slope of the data points with the time.

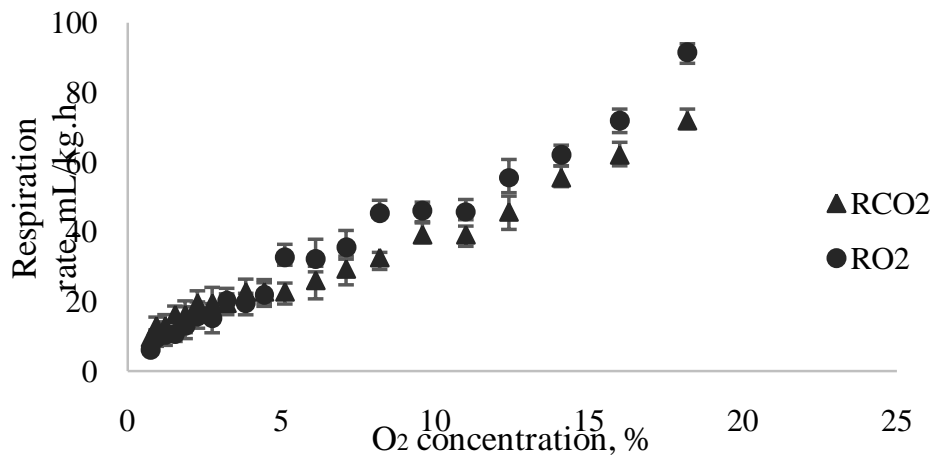

Figure 2:- Change in respiration rate with increase in concentration of $\mathrm{CO}_{2}$ and decrease in $\mathrm{O}_{2}$ concentration at 5

${ }^{\circ} \mathrm{C}$.Data correspond to the mean $\pm \mathrm{SE}$ of the independent triplicates.

The respiratory quotient $(R Q)$, estimated as the ratio of $\mathrm{CO}_{2}$ evolved to the $\mathrm{O}_{2}$ consumed, was found to vary with time for all the temperature levels studied. Similar results of variation with time and temperature were reported by earlier researchers (Bhande and Goswami, 2008; Mangaraj and Goswami, 2011). Nakamura et al., (2004)also reported similar temperature dependence of $R Q$ for mangoes. The $R Q$ above 1.3 indicates that the respiration has turned into anaerobic respiration, the process being termed as anaerobiasis (Kader, 1986;Iqbal et al., 2009). This was evident by off-odor produced inside the chamber after the onset of anaerobiasis. In the present study, the tolerance limits for oyster mushrooms were found to be $17.2 \%$ of $\mathrm{CO}_{2}$ (maximum) and $1.55 \%$ of $\mathrm{O}_{2}$ (minimum), i.e. the gas concentration after which the anaerobiasis sets in and the value of $R Q$ exceeds 1.3.This combination of gases can, therefore, be used as the basis of selection of range for optimization of gas concentration in MAP for oyster mushrooms.

\section{Estimation of model parameters:- \\ Model1 (Peleg model)}

The values of model parameters $a$ and $b$ of the regression equation indicated the temperature dependence of both the parameters, whereas, the temperature had more a pronounced influence on $b$ than $a$. The model parameters $a$ corresponds to rate constant that explains the influence of consumption and evolution rate of gases in the initial stages of respiration. Whereas, $b$, is the capacity constant that relates to the attainable gas concentrations by the system when the time approaches to infinity and at that moment the above equations establish the relation between 
the equilibrium gas content and $b$. The values of $a$ and $b$ obtained in this study were found to have slightly higher, but similar trend of the parameters reported for the respiration of apples by Mahajan and Goswami (2001) and banana by Bhande and Goswami(2008). This increase in the values of the parameters $a$ and $b$ as compared to the literature values of banana and apple could be attributed to the higher respiration rate of mushrooms. The values of regression coefficients $a$ and $b$ of Eqs. 4 and 5, and correlation coefficients $\left(R^{2}\right)$ at different storage temperatures are presented in Table 2. Since the $R^{2}>0.992$, the regression functions suitably fitted the experimental data for mushrooms.

Table 2:- Regression co efficients $a$ and $b$ of Peleg model at different storage temperatures for consumption of $\mathrm{O}_{2}$ and evolution of $\mathrm{CO}_{2}$, respectively

\begin{tabular}{|c|c|c|c|c|c|c|}
\hline \multirow{2}{*}{ Temperature } & \multicolumn{3}{|c|}{$\mathrm{CO}_{2}$} & \multicolumn{3}{|c|}{$\mathrm{O}_{2}$} \\
\cline { 2 - 7 } & $a\left(\mathrm{~h}^{-1}\right)$ & $b\left(\%^{-1}\right)$ & Adj. $R^{2}$ & $a\left(\mathrm{~h}^{-1}\right)$ & $b\left(\%{ }^{-1}\right)$ & \multicolumn{1}{|c|}{ Adj. $R^{2}$} \\
\hline 0 & $3.17 \pm 0.02$ & $378.49 \pm 5.03$ & 0.999 & $3.11 \pm 0.53$ & $211.44 \pm 9.21$ & 0.998 \\
\hline 5 & $3.26 \pm 0.13$ & $254.76 \pm 6.04$ & 0.998 & $3.24 \pm 0.41$ & $178.83 \pm 11.33$ & 0.998 \\
\hline 10 & $3.46 \pm 0.09$ & $174.61 \pm 4.22$ & 0.997 & $3.49 \pm 0.75$ & $112.92 \pm 6.16$ & 0.999 \\
\hline 15 & $3.61 \pm 0.19$ & $121.34 \pm 6.54$ & 0.998 & $3.92 \pm 0.51$ & $88.33 \pm 7.27$ & 0.994 \\
\hline 20 & $3.89 \pm 0.01$ & $78.32 \pm 7.21$ & 0.997 & $4.35 \pm 0.82$ & $62.33 \pm 5.52$ & 0.994 \\
\hline 25 & $4.28 \pm 0.42$ & $52.31 \pm 5.15$ & 0.994 & $4.53 \pm 0.32$ & $57.76 \pm 6.64$ & 0.998 \\
\hline 30 & $4.92 \pm 0.45$ & $22.94 \pm 5.03$ & 0.999 & $4.81 \pm 0.23$ & $24.99 \pm 3.08$ & 0.998 \\
\hline
\end{tabular}

Values in the table are average of three replications and values after \pm are standard deviation.

The values of model parameters $a$ and $b$ of different storage temperatures were found to follow zero order kinetics (Figure 3) and the model equations found can be used for the prediction of model parameters for a given combination of gases (i.e. $\mathrm{CO}_{2}$ and $\mathrm{O}_{2}$ ). This method yields more precise values, otherwise, the value of $a$ and $b$ can also be determined by linear interpolation of the known values. The Eqs. 6 and 7 can be used to estimate $d G O_{2} / d t$ and $d G \mathrm{CO}_{2} / d t$ by substituting the corresponding values of $a$ and $b$, respectively, that can further be substituted in the Eqs. 1 and 2 for the prediction of respiration of respiration rate by model 1 .
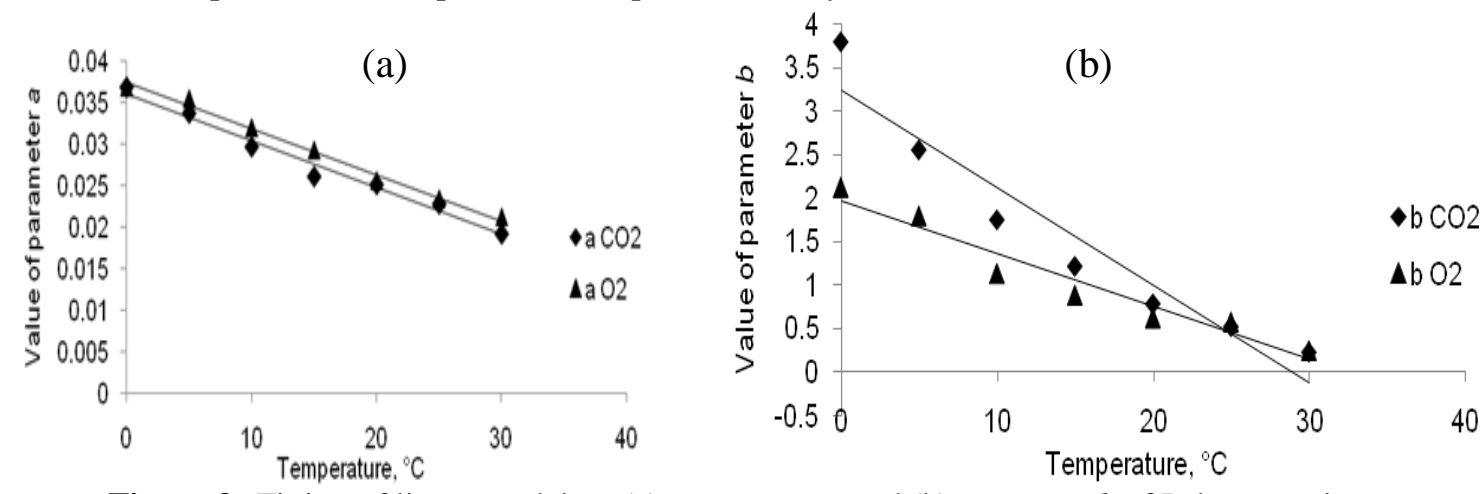

Figure 3:-Fitting of linear model on (a) parameter $a$ and (b) parameter $b$ of Peleg equation.

\section{Model 2 (uncompetitive inhibition based enzyme kinetics model)}

The multiple linear regression analysis was used to estimate the model parameters (Table 3 and 4). The model parameters showed temperature dependence, which was established by fitting the Arrhenius model on the model parameters against the inverse of absolute temperature. All the model parameters $\left(R_{\mathrm{m}}\right)$ such as $V_{\mathrm{m}}, K_{\mathrm{m}}$, and $K_{\mathrm{i}}$ for $\mathrm{O}_{2}$ and $\mathrm{CO}_{2}$ (both oxidative as well as fermentative) were plotted as a natural logarithm against the difference of inverse of absolute temperature and the reference temperature in the linear form (Eq. 15).

In case of competitive inhibition, the inhibition by $\mathrm{CO}_{2}$ can be counteracted by increasing $\mathrm{O}_{2}$, because both the gases $\left(\mathrm{O}_{2}\right.$ and $\left.\mathrm{CO}_{2}\right)$ are competing for the same active site. But in case of uncompetitive inhibition, the $\mathrm{CO}_{2}$ reacts with enzyme substrate complex, therefore, increase in the concentration of $\mathrm{O}_{2}$ will not be able to counteract $\mathrm{CO}_{2}$ as there is always some amount of enzyme-substrate complex available for $\mathrm{CO}_{2}$ to bind. Hence, the maximum respiration rate $\left(V_{m}\right)$ would never be achieved until the presence of $\mathrm{CO}_{2}$ or at the beginning of the experiment when $\mathrm{CO}_{2}$ is very low. The high values of $V_{\mathrm{m}}$ (maximum respiration rate), indicate that the respiration rate was strongly affected by increase in temperature and were found to be in agreement with those reported in the literature(Mahajan and Goswami, 2001; Mangaraj and Goswami, 2011). 
Table 3:- Model parameters for uncompetitive inhibition enzyme kinetics based model at different storage temperatures

\begin{tabular}{|l|l|l|l|l|l|}
\hline $\begin{array}{l}\text { Storage } \\
\text { tempera- } \\
\text { ture, }{ }^{\circ} \mathrm{C}\end{array}$ & $\begin{array}{l}\text { Respiration } \\
\text { expression in terms } \\
\text { of }\end{array}$ & \multicolumn{2}{|l|}{ Enzyme kinetics coefficients } & $\begin{array}{l}\text { Coefficient of } \\
\text { determination } \\
\left(\text { Adj. } R^{2}\right)\end{array}$ \\
\cline { 3 - 6 } & & $\begin{array}{l}V_{\mathrm{m}} \\
\left(\mathrm{mL} \mathrm{kg}^{-1} \mathrm{~h}^{-1}\right)\end{array}$ & $\begin{array}{l}K_{\mathrm{m}} \\
\% \mathrm{O}_{2}\end{array}$ & $\begin{array}{l}K_{\mathrm{i}} \\
\% \mathrm{CO}_{2}\end{array}$ & \\
\hline 0 & $\mathrm{CO}_{2}$ evolution & $35.81 \pm 3.87$ & $8.14 \pm 1.12$ & $12.13 \pm 3.01$ & 0.938 \\
& $\mathrm{O}_{2}$ consumption & $28.98 \pm 4.14$ & $7.87 \pm 1.36$ & $9.76 \pm 2.15$ & 0.992 \\
\hline 5 & $\mathrm{CO}_{2}$ evolution & $176.99 \pm 12.32$ & $9.27 \pm 1.73$ & $11.89 \pm 3.52$ & 0.983 \\
& $\mathrm{O}_{2}$ consumption & $173.41 \pm 12.18$ & $8.32 \pm 2.81$ & $8.95 \pm 2.57$ & 0.995 \\
\hline 10 & $\mathrm{CO}_{2}$ evolution & $188.55 \pm 19.41$ & $10.33 \pm 1.01$ & $10.15 \pm 2.23$ & 0.998 \\
& $\mathrm{O}_{2}$ consumption & $192.87 \pm 11.87$ & $9.23 \pm 1.33$ & $8.02 \pm 1.36$ & 0.995 \\
\hline 15 & $\mathrm{CO}_{2}$ evolution & $203.25 \pm 12.01$ & $11.15 \pm 2.15$ & $9.03 \pm 2.43$ & 0.961 \\
& $\mathrm{O}_{2}$ consumption & $213.45 \pm 13.36$ & $10.45 \pm 0.91$ & $7.42 \pm 1.95$ & 0.976 \\
\hline 20 & $\mathrm{CO}_{2}$ evolution & $298.34 \pm 17.74$ & $12.87 \pm 2.21$ & $8.78 \pm 1.56$ & 0.988 \\
& $\mathrm{O}_{2}$ consumption & $308.78 \pm 12.14$ & $11.98 \pm 1.32$ & $6.57 \pm 0.93$ & 0.935 \\
\hline 25 & $\mathrm{CO}_{2}$ evolution & $354.56 \pm 21.24$ & $13.54 \pm 1.43$ & $7.88 \pm 1.51$ & 0.979 \\
& $\mathrm{O}_{2}$ consumption & $369.43 \pm 24.92$ & $13.14 \pm 3.32$ & $6.34 \pm 1.42$ & 0.984 \\
\hline 30 & $\mathrm{CO}_{2}$ evolution & $436.68 \pm 25.34$ & $14.06 \pm 1.72$ & $6.74 \pm 1.81$ & 0.985 \\
& $\mathrm{O}_{2}$ consumption & $574.72 \pm 26.87$ & $13.41 \pm 2.83$ & $5.72 \pm 1.72$ & 0.993 \\
\hline
\end{tabular}

Values in the table are average of three replications and values after \pm are standard deviation.

Table 4:- Model parameters of uncompetitive inhibition enzyme kinetics based model for fermentative $\mathrm{CO}_{2}$ production at different storage temperatures.

\begin{tabular}{|l|l|l|l|}
\hline Storage temperature, ${ }^{\circ} \mathrm{C}$ & $V_{m(\mathrm{CO}) f}$ & $K_{m(O 2) f}$ & $\begin{array}{l}\text { Coefficient of } \\
\left.\text { determination (Adj. } R^{2}\right)\end{array}$ \\
\hline 0 & $62.02 \pm 9.82$ & $1.94 \pm 0.43$ & 0.86 \\
\hline 5 & $137.06 \pm 19.59$ & $2.95 \pm 0.63$ & 0.91 \\
\hline 10 & $187.13 \pm 32.23$ & $3.28 \pm 0.81$ & 0.91 \\
\hline 15 & $204.39 \pm 41.9$ & $5.07 \pm 2.66$ & 0.90 \\
\hline 20 & $289.38 \pm 32.56$ & $8.36 \pm 1.13$ & 0.91 \\
\hline 25 & $360.74 \pm 28.45$ & $9.31 \pm 2.41$ & 0.93 \\
\hline 30 & $454.13 \pm 40.19$ & $11.71 \pm 2.41$ & 0.89 \\
\hline
\end{tabular}

Values are average of three replications and values after \pm are standard deviation.

$K_{m}$ is the measure of saturation of respiration by $\mathrm{O}_{2}$ at which $V_{m}$ becomes half $\left(1 / 2 V_{m}\right)$ when there is no inhibition by $\mathrm{CO}_{2}$ and the values of parameter $K_{m}$ at different temperature were found similar to the literature (Bhande and Goswami, 2008; Menon and Goswami, 2008; Mangaraj and Goswami, 2011). The value for $K_{i}$ is a measure of the degree to which the respiration (both in terms of $\mathrm{CO}_{2}$ production and $\mathrm{O}_{2}$ consumption) can be inhibited by $\mathrm{CO}_{2}$. The higher values of $K_{i}$ show the backward reaction is faster than the forward reaction and hence, there is no inhibition in respiration due to $\mathrm{CO}_{2}$ (Hertoget al., 1998). In the present study, the values of $K_{i(\mathrm{CO} 2)}$ and $K_{i\left(\mathrm{O}_{2}\right)}$ for mushrooms indicated that the respiration was inhibited by $\mathrm{CO}_{2}$ and the values were similar to the literature (Bhande and

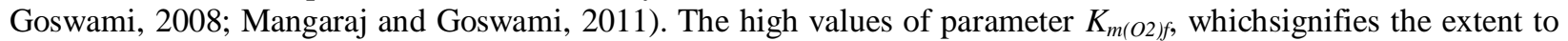
which fermentation can be inhibited by $\mathrm{O}_{2}$ indicate that the mushrooms show fermentative $\mathrm{CO}_{2}$ production at even higher levels of $\mathrm{O}_{2}$.

There was a change in the trend of the linear plot of Arrhenius equations and it appeared to have two different regions which can be attributed to the change in rate limiting enzymatic action due to the change in storage temperature (Song et al., 1992). The values of activation energy and the respiration pre-exponential factor were calculated from the slope and $y$-axis intercept and are presented in Table 5. The negative value of the activation energy for parameter $K_{\mathrm{i}}$ indicated that the temperature had a negative effect on the inhibition by $\mathrm{CO}_{2}$, which means with the increase in temperature the inhibitory effect of $\mathrm{CO}_{2}$ was less pronounced (Bhande and Goswami, 2008). These constants can be used to predict the values of model parameters of equations ( 8 and (9) at any temperature, and which in turn can be used to predict the respiration rate for any given combination of gaseous concentration i.e. $\mathrm{CO}_{2}$ and $\mathrm{O}_{2}$. 
Table 5:- Parameters of Arrhenius equation for different model parameters for uncompetitive inhibition based enzyme kinetics model.

\begin{tabular}{|c|c|c|c|c|c|c|}
\hline \multirow[t]{2}{*}{$\begin{array}{l}\text { Parameters of } \\
\text { Arrhenius equation }\end{array}$} & \multicolumn{2}{|c|}{$\begin{array}{l}\text { Maximum respiration rate, } \\
\left(V_{\mathrm{m}}\right), \mathrm{mL} \cdot \mathrm{kg}^{-1} \cdot \mathrm{h}^{1}\end{array}$} & \multicolumn{2}{|c|}{$\begin{array}{l}\text { Michaelis-Menten equation, } \\
\left(K_{\mathrm{m}}\right), \% \mathrm{O}_{2}\end{array}$} & \multicolumn{2}{|c|}{ Inhibition constant $\left(K_{\mathrm{i}}\right), \% \mathrm{O}_{2}$} \\
\hline & $\mathrm{O}_{2}$ & $\mathrm{CO}_{2}$ & $\mathrm{O}_{2}$ & $\mathrm{CO}_{2}$ & $\mathrm{O}_{2}$ & $\mathrm{CO}_{2}$ \\
\hline 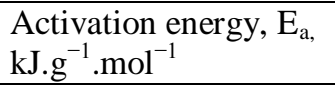 & $43.2 \pm 1.39$ & $32.71 \pm 1.16$ & $37.18 \pm 1.25$ & $40.59 \pm 1.42$ & $-26.01 \pm 1.11$ & $-38.15 \pm 1.31$ \\
\hline $\begin{array}{l}\text { Pre-exponential factor, } \\
R_{\mathrm{p}}\end{array}$ & $223.7 \pm 2.16$ & $225.65 \pm 2.43$ & $4.48 \pm 0.36$ & $3.62 \pm 0.28$ & $3.09 \pm 0.21$ & $3.83 \pm 0.17$ \\
\hline $\mathrm{R}^{2}$ & 0.98 & 0.97 & 0.99 & 0.94 & 0.97 & 0.98 \\
\hline \multicolumn{4}{|c|}{ Parameters for fermentative $\mathrm{CO}_{2}$ production } & $V_{m(\mathrm{CO} 2) f}$ & & $K_{m(O 2) f}$ \\
\hline \multicolumn{4}{|c|}{ Activation energy, $\mathrm{E}_{\mathrm{a}, \mathrm{kJ} . \mathrm{g}^{-1} \cdot \mathrm{mol}^{-1}}$} & 40.32 & & 42.94 \\
\hline \multicolumn{4}{|c|}{ Pre-exponential factor, $R_{\mathrm{p}}$} & 208 & & 5.24 \\
\hline \multicolumn{4}{|l|}{$\mathrm{R}^{2}$} & 0.92 & & 0.97 \\
\hline
\end{tabular}

\section{Validation of the Models:-}

In order to find the suitability of the developed models for the prediction of the respiration rate within the experimental domain, validation is necessary. Since, the experiments were conducted from 0 to $30{ }^{\circ} \mathrm{C}$ with the step of $5{ }^{\circ} \mathrm{C}$, validation of the model was conducted at $3{ }^{\circ} \mathrm{C}$ storage temperature. The respiration rates of mushrooms in terms of $\mathrm{O}_{2}$ consumption and $\mathrm{CO}_{2}$ evolution were estimated by using Eqs. 1 and 2. The predicted and actual respiration rates of mushrooms as presented in Figures 4 and 5 in terms of $\mathrm{CO}_{2}$ and $\mathrm{O}_{2}$, respectively, showed that the mean relative deviation moduli of predicted versus experimental respiration rates for model 1 (Peleg model) were found to be $10.3 \%$ and $11.2 \%$ for $\mathrm{O}_{2}$ and $\mathrm{CO}_{2}$ respiration expressions and $9.3 \%$ and $8.5 \%$ for $\mathrm{O}_{2}$ and $\mathrm{CO}_{2}$ for model 2(uncompetitive inhibition based enzyme kinetics model), respectively.

Although the predicted respiration rates of mushrooms for both the models used in the study were in close agreement with the experimental respiration rates. The study suggested that the uncompetitive inhibition based enzyme kinetics model showed more uniformity in the prediction of respiration rate in terms of closeness to the actual respiration rate over the entire experimental temperature range. Also the uncompetitive inhibition based enzyme kinetics model is more generic and complete model and could be fully predictive and extrapolated out of current boundary conditions (i.e. different levels of $\mathrm{O}_{2}$ and $\mathrm{CO}_{2}$ concentrations). Although the respiration is mainly affected by gas concentration and temperature, the time also plays a crucial role in the respiration rate (Azevedoet $a l ., 2014)$ and, therefore, the Peleg model was also used for modeling the respiration rate.

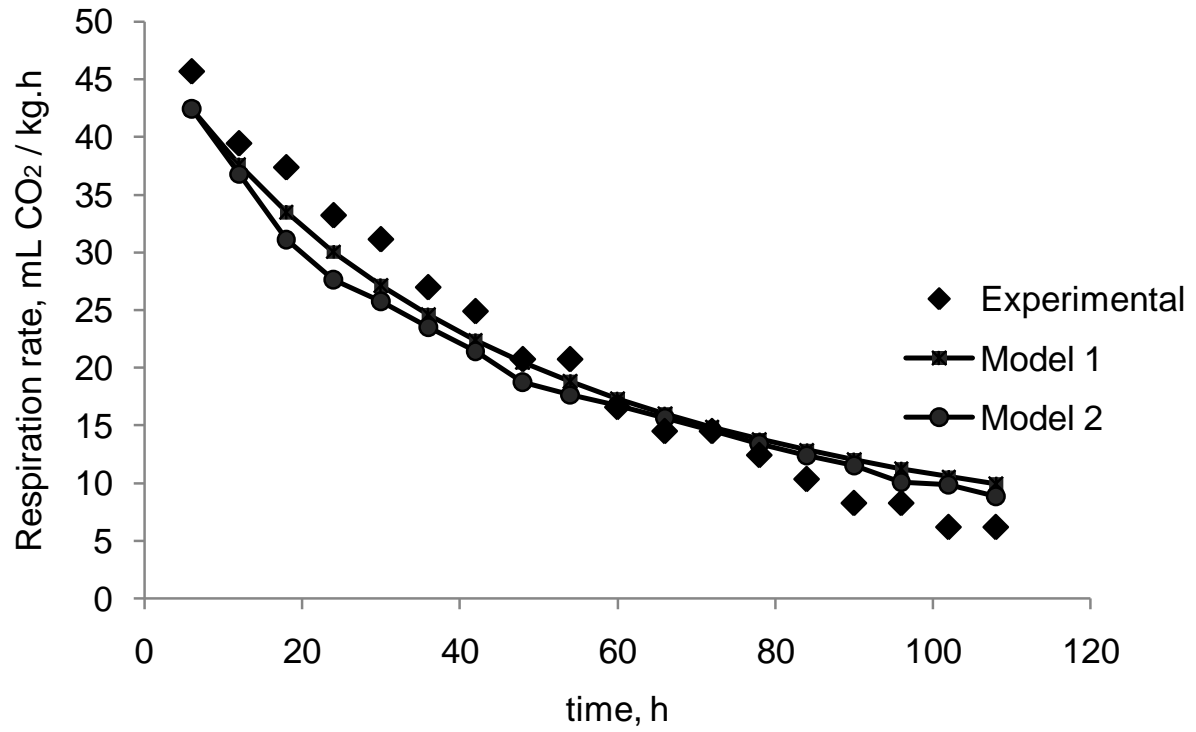

Figure 4:- Predicted and experimental respiration rate of mushrooms at $3{ }^{\circ} \mathrm{C}$ in terms of $\mathrm{CO}_{2}$ evolution. 


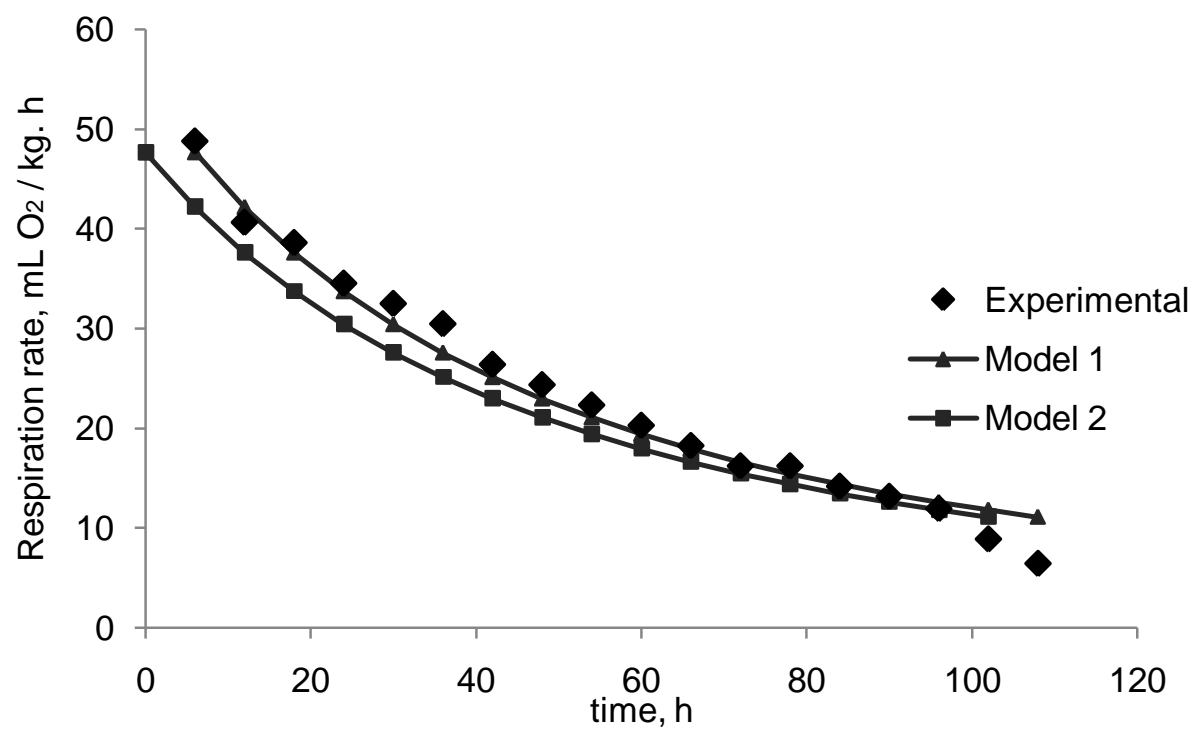

Figure 5:- Predicted and experimental respiration rate of mushrooms at $3{ }^{\circ} \mathrm{C}$ in terms of $\mathrm{O}_{2}$ consumption.

\section{Conclusions:-}

The respiration rate of the mushrooms increased with temperature, but it decreased with the storage time as compared to the initial respiration rate at time zero. This trend could be attributed to the diminishing amounts of $\mathrm{O}_{2}$ and accumulation of $\mathrm{CO}_{2}$. The models developed were found suitable for the prediction of respiration rate of mushrooms within the experimental range i.e. from 0 to $30^{\circ} \mathrm{C}$. The respiration rate predicted by the regression (Peleg) model and uncompetitive inhibition type enzyme kinetics model showed close agreement with the experimentally determined respiration rate of the mushrooms at $3^{\circ} \mathrm{C}$.

Based on the Arrhenius equation with a new term, the reference temperature $\left(T_{r e f}\right)$, a temperature dependent model was also developed which has shown a significant effect of temperature on the respiration rate of mushrooms. By the use of the term $T_{\text {ref }}$ in the Arrhenius equation, the pre-exponential factor $R_{\mathrm{p}}$ becomes equal to the respiration rate of the mushrooms at the reference temperature. The models developed are specific to that cultivar of mushrooms and are, therefore, valid only within the temperature where experiments were conducted i.e. from 0 to $30^{\circ} \mathrm{C}$ storage temperatures. Furthermore, the activation energy and pre-exponential factor of the Arrhenius equation were found to be useful for predicting the model parameters at given range of storage temperatures of 0 to $30^{\circ} \mathrm{C}$. The information obtained regarding the respiration rate and the developed models would be of immense help in designing MAP and AP system for the oyster mushrooms.

\section{Funding:-}

This research received no specific grant from any funding agency in the public, commercial, or not-for-profit sectors.

\section{Acknowledgements:-}

The authors gratefully acknowledge the financial support provided by the Department of Biotechnology, Govt. of India, New Delhi, for carrying out this research work.

\section{Conflict of interest:-}

The authors declare that there is no conflict of interest.

\section{References:-}

1. Aida, F.M.N.A., Shuhaimi, M., Yazidi, M.and Maaruf, A.G. (2009): Mushroom as a potential source of prebiotics: a review. Trends Food Sci. Technol., 20: 567-575.

2. Azevedo, S., Cunha, L.M.and Fonseca, S.C. (2014): Modelling the influence of time and temperature on the respiration rate of fresh oyster mushrooms. Food Sci. Technol. Int.,21(8): 1-11. 
3. Bano, Z.,Rajarathnam, S.and Steinkraus, K.H. (1988):Pleurotus mushrooms. Part II. Chemical composition, nutritional value, post-harvest physiology, preservation, and role as human food. Crit. Rev. Food Sci. Nutr.,27: 87-158.

4. Bhande, S.D., Ravindaran, M.R.andGoswami, T.K. (2008): Respiration rates of banana fruits under aerobic conditions at different storage temperatures. J. Food Eng.,87:116-123.

5. Bron, I.U., Ribeiro, R.V., Cavalini, F.V., Jacomino, A.P. andTrevisan, M.J. (2005): Temperature related changes in respiration and Q10 coefficient of guava. Sci. Agric., 62(5): 458-463.

6. Byrnes, V.C.andO'Beirne, D. (2007): Effects of gas atmosphere and temperature on the respiration rate of whole and sliced mushrooms (Agricus bisporus) - Implications for film permeability in modified atmosphere packages. J. Food Sci., 72(4): 197-207.

7. Cameron, A.C., Boylan-Pett, W.and Lee, J. (1989): Design of modified atmosphere-packaging systems: modeling oxygen concentrations within sealed packages of tomato fruits. J. Food Sci., 54: 1413-1415.

8. Cheung, P.C.K. (2008): Mushrooms as Functional Foods. John Wiley \& Sons, Inc, 3, 23-24.

9. Fonseca, S.C., Oliveira, F.A.R., Frias, J.M., Brecht, J.K.andChau, K.V. (2002): Modelling respiration rate of shredded Galega kale for development of modified atmosphere packaging. J. Food Eng.,54(4): 299-307.

10. Hagger, P.E., Lee, D.S.and Yam, K.L. (1992): Application of an enzyme kinetic based respiration model to closed system experiments for fresh produce. J. Food Process Eng., 15: 143-157.

11. Hertog, M.L.A.T.M., Peppelenbos, H.W., Evelo, R.G.andTijskens, L.M. (1998): A dynamic and generic model on the gas exchange of respiring produce: the effects of oxygen, carbon dioxide and temperature. Postharvest Biol. Technol., 14: 335-349.

12. Ho, Q.T., Verboven, P., Verlinden, B.E., Lammertyn, J., Vandewalle, S. and Nicolai, B.M. (2008): A continuum model for metabolic gas exchange in pear fruit. PLoSComput. Biol.,4(3): 1-13.

13. Ho, Q.T., Verboven, P., Verlinden, B.E.and Nicolai, B.M. (2008): A model for gas transport in pear fruit at multiple scales. J. Exp. Bot.,61(8): 2071-2081.

14. Hong, S.and Kim, D. (2001): Influence of oxygen concentration and temperature on respiratory characteristics of fresh-cut green onion. Int. J. Food Sci. Technol., 36(3): 283-289.

15. Iqbal, T., Rodrigues, F.A.S., Mahajan,P.V.and Kerry, J.P. (2009): Mathematical modelling of influence of temperature and gas composition on the respiration rate of shredded carrots. J. Food Eng.,91: 325-332.

16. Kader, A.A. (1986): Biochemical and physiological basis for effects of controlled and modified atmospheres on fruits and vegetables. Food Technol., 40: 99-104.

17. Kader, A.A. (2006): Mango-recommendations for maintaining postharvest quality. /Http://Postharvest.Ucdavis.Edu/Produce/ Producefacts/Fruit/Mango.Shtmls. Viewed On 29 October 20014.

18. Kays, S.J. (1991): Metabolic processes in harvested products respiration. Postharvest physiology of perishable plant products. Van Nostrand Reinhold Publication, NY.

19. Koopman, R.and Laney, K. (2010): Mushrooms, Industry and trade. United States International Trade Commission Publication, ITS-07.

20. Koushki, M.R., Khoshgozaran, A.S., Mohammadi, M., Hadian, Z., Bagheri, P.N., Sharayei, P.and Mortazavian, A.M. (2011): Physicochemical properties of mushrooms as affected by modified atmosphere packaging and $\mathrm{CaCl}_{2}$ dipping. Afr. J. Agric. Res., 6(24): 5414-5421.

21. Lakakul, R., Beaudry, R.M.and Hernandez, R. J. (1999): Modeling respiration of apple slices in modifiedatmosphere packages. J. Food Sci., 64: 105-110.

22. Lammertyn, J., Scheerlinck, N., Jancsok, P., Verlinden,B.E. and Nicolai, B.M. (2003): A respiration-diffusion model for 'Conference' pears I: model development and validation. Postharvest Biol. Technol.,30: 29-42.

23. Lee, D.S., Hagger, P.E., Lee, J.and Yam, K.L. (1991): Model for fresh produce respiration in modified atmosphere based on principles of enzyme kinetics. J. Food Sci., 56: 1580-1585.

24. Lee, J.J.and Lee, D.S. (1996): A dynamic test for kinetic model of fresh produce respiration in modified atmosphere and its application to packaging of prepared vegetables. Food Sci. Biotechnol., 5(4): 343-348.

25. Li, X., Wang, X., Wang, J.and Liu, Z. (2009): Respiration rate models of Agaricus bisporus under modified atmosphere packaging. Int. J. Food Eng.,5: Article 7. doi:10.2202/1556-3758.1706.

26. Mahajan, P.V. andGoswami,T.K. (2001): Enzyme kinetics based modeling of respiration rate for apple. J. Agric. Eng. Res., 79: 399-406.

27. Makino, Y., Iwasaki, K.and Hirata, T. (1996): Oxygen consumption model for fresh produce on the basis of adsorption theory. Trans. ASAE., 39: 1067-1073.

28. Mangaraj, S.andGoswami, T.K. (2011): Measurement and modelling of respiration rate of Guava (cv. Baruipur) for modified atmosphere packaging. Int. J. Food Prop.,14(3): 609-628. 
29. Mclaughlin, C.P.andO'Beirne, D. (1999): Respiration rate of a dry coleslaw mix as affected by storage temperature and respiratory gas concentrations. J. Food Sci., 64: 116-119.

30. Menon, R.R.andGoswami, T.K. (2008): Modelling the respiration rate of green mature mango under aerobic conditions. Bioprocess Biosyst. Eng.,99: 239-248.

31. Morales-Castro, J., Rao, M.O., Hotchkiss, J.H.and Downing, D.L. (1994): Modified atmosphere packages of head lettuce. J. Food Process. Preserv.,18: 295-304.

32. Nakamura, N., Rao, D.V.S., Shiina, T.andNawa, Y. (2004): Respiration properties of tree-ripe mango under CA condition. Jpn. Agric. Res. Q.,38(4): 221-226.

33. Oliveira, F., Sousa-Gallagher, M.J., Mahajan, P.V.and Teixeira, J.A. (2012): Development of shelf life kinetic model for modified atmosphere packaging of fresh sliced mushrooms. J. Food Eng.,111: 466-473.

34. Peleg, M. (1988): An empirical model for the description of moisture sorption curves. J. Food Sci., 53: 12161217.

35. Peppelenbos, H.W., Tijskens, L.M.M., van'tLeven, J. and Wilkinson, E.C. (1996): Modelling oxidative and fermentative carbon dioxide production of fruits and vegetables. Postharvest Biol. Technol.,9: 283-295.

36. Powrie, W.D.andSkura, B. (1991): Modified atmosphere packaging of fruits and vegetables. In: Modified atmosphere packaging of foods,B. Ooraikul and M.E. Stiles. (eds), Ellis Horwood, West Sussex.

37. Rai, R.D.andArumuganathan, T. (2008): Postharvest technology of mushrooms. National Research Centre for Mushroom(ICAR)Chambaghat, Solan - 173213 (HP), India.

38. Sapata, M., Ramos, A., Ferreira, A., Andrada, L.andCandeias, M. (2009): Changes of quality of Pleurotus ssp. carpophores in modified atmosphere packaging. Acta Sci. Pol., Technol. Aliment.,8:17-22.

39. Saltveit, M.E. (2004): Respiratory metabolism. In: The commercial storage of fruits, vegetables, and florist and nursery stocks, Agriculture Handbook Number. 66, USDA.

40. Schwaab, M.and Pinto, J.C. (2007): Optimum reference temperature for reparameterization of the Arrhenius equation. Part 1: Problems involving one kinetic constant. Chem. Eng. Sci.,62: 2750-2764.

41. Solomos, T. (1983): Respiration and energy metabolism in senescing plant tissue. In: Post harvest physiological and crop preservation, M. Lieberman (Ed.) p. 61. Plenum Press, Oxford.

42. Song, Y., Kim, H.K.and Yam, K.L. (1992): Respiration rate of blueberry in modified atmosphere at various temperatures. J. Am. Soc. Hortic. Sci.,117: 925-929.

43. Talasila, P.C., Chau, K.V.and Brecht, J.K. (1992): Effects of gas concentrations and temperature on $\mathrm{O}_{2}$ consumption of strawberries. Trans. ASAE., 35: 221-224.

44. Turhan, M., Seyar, S.andGunasekaran, S. (2002): Application of Peleg model to study water adsorption in chickpea during soaking. J. Food Eng.,53: 153-59.

45. Villaescusa, R.and Gil, M. (2003): Quality improvement of Pleurotus mushrooms by modified atmosphere packaging and moisture absorbers. Postharvest Biol. Technol., 28: 169-179.

46. Yang, C.C.andChinnan, M.S. (1988): Modelling the effect of $\mathrm{O}_{2}$ and $\mathrm{CO}_{2}$ on respiration and quality of stored tomatoes. Trans. ASAE., 30: 920-925. 